5. Egorov, RS, (2007). The causal structure of the disorder of adaptive reactions in the military service of emergency service, Siberian Journal of Psychiatry and narcology, 1, 222.

6. Karayani, AG \& Syromyatnikov, IV, 2006. Applied Military Psychology. St. Petersburg: Peter, 480s

7. Vasilieva, O.S. \& Radyshevskaya, Ya.B., (2005). Influence of aggression of cadets on the level of their social and psychological adaptation. Questions of psychology, 1, 29-37.

8. Tokhtamysh, OM, 2018. Post traumatic growth in the rehabilitation process. Bulletin of the Taras Shevchenko National University of Kyiv. Social work 1 (3), 57-62.

N. Hryb, Master student

Taras Shevchenko National University of Kyiv, Kyiv, Ukraine
9. Volyansky, E.V., 2001. The main stages of the systematic study of aggression. Methodology, theory and practice of sociological analysis of modern society: Zb.nauc.pr., 179-183.

10. Petrova, AB, 2008. Psychological correction and prevention of aggressive forms of behavior of minors with deviant behavior. $\mathrm{M}$.: Flint, MPSI

Надійшла до редколегії 01.11.18 Рецензовано 16.11.18

\title{
PREVENTION OF MILITARY STAFF' DESTRUCTIVE AGGRESSIVENESS
}

The work is devoted to the current theme, because in today's socio-psychological insecurity in Ukraine there is no comprehensive approach to the organization of socio-psychological prevention of the consequences of psychotraumatic exacerbations of destructive aggression of servicemen who suffered in the conditions of participation in hostilities. The aim of the work is not only a theoretical analysis of the problem, but also a practical study of the current situation. This allows us to make conclusions and preventive recommendations, which in the future can be introduced into the professional practice of not only social workers, psychologists, but also commanders and rehabilitants.

Therefore, the purpose of the study is to explore the main individual and psychological determinants of the formation of destructive aggressiveness and to develop on the basis of these appropriate directions of rehabilitation work to prevent it from servicemen. Empirical methods (observation, expert assessment of staff psychologists and commanders) were used for the study in order to identify soldiers who had destructive aggression after engaging in combat operations, interviewing, forming experiment, testing with psychodiagnostic techniques.The developed corrective program revealed a positive dynamics of personality changes that began to occur in the behavior of servicemen under the action of the measures taken. The training resulted in a significant decrease in physical aggression, a slight decrease in verbal aggression, a slight increase in indirect aggression. It is proved that the individual correction of consciousness and behavior of each serviceman inclined to aggressive actions, as well as the neutralization of negative interpersonal influences, provoking aggressive manifestations in the military. Such prevention can be carried out during a stressful situation, manifestation of aggression or after the end of an aggressive state. This program can be carried out during the service in part and after returning from the area of hostilities.

Keywords: serviceman, fighting, aggression, traumatic influence, destructive aggressiveness, professional readiness.

Н. Гриб, магистр

Киевский национальный университет имени Тараса Шевченко, Киев, Украина

\section{ПРОФИЛАКТИКА ДЕСТРУКТИВНОЙ АГРЕСИВНОСТИ У ВОЕННОСЛУЖАЩИХ}

Работа посвящена актуальной в настоящее время теме, ведь в условиях современной социально-психологической незащищенности в Украине отсутствует комплексный подход организации социально-психологической профилактики последствий психотравмирующей обостренной деструктивной агрессивности военнослужащих, пострадавших в условиях участия в боевых действиях. Целью работы является не только теоретический анализ проблемы, но и практическое исследование ситуации. Это позволяет сделать выводы и профилактические рекомендации, которые в дальнейшем можно внедрять в профессиональную практическую деятельность не только социальных работников, психологов, но и командиров.

Ключевые слова: военнослужащий, боевые действия, агрессия, психотравмирующие влияние, деструктивная агрессивность, профессионально оправдана агрессивность.

УдК 364.044.42

DOI: https://doi.org/10.17721/2616-7786.2018/4-1/10

О. Тохтамиш, канд. психол. наук, доц. Київський національний університет імені Тараса Шевченка, Київ, Україна ORCID iD 0000-0002-3850-535X

B. Пархоменко, магістр ГО Клуб "Еней" ORCID iD 0000-0003-4400-7397

A. Сарнацька, головний спеціаліст ГО Клуб "Еней", Київ, Україна ORCID iD 0000-0002-5253-291X

\section{ТЕХНОЛОГІЯ "WINGS" ЯК ЗАСІБ ПРОТИДIÏ НАСИЛЬСТВУ СТОСОВНО ЖІНОК ІЗ ГРУПИ ПІДВИЩЕНОГО РИЗИКУ}

Розглядаються фонкціональні складові комплексної профрілактичної та реабілітаційної технології "WINGS" (Women Initiating New Goals of Safety), розробленої групою соціальної інтервенції Колумбійського університету (США), з метою зниження ризику насильства щодо жінок з наркозалежністю. Аналізуються результати емпіричного дослідження ефективності ії застосування у ролі пілотного проекту в Україні. Пропонуються рекомендації щодо вдосконалення ії застосування з урахуванням отриманих результатів.

Ключові слова: профілактика насильства, жінки з наркозалежністю, короткотривале втручання, гендернозумовлене насильство, соціальний супровід.

Вступ. Розвиток соціальних послуг у демократичному суспільстві потребує аналізу ефективності та застосування передових інноваційних технологій, втілених також у діяльності соціальних служб інших країн [1; 2; 3]. Особливо це стосується соціального супроводу, профілактичних та інтервенційних засобів у соціальних службах, які працюють 3 сім'ями [4] та самотніми жінками з груп підвище- ного ризику, які належать до найменш захищених верств населення. Однією з актуальних проблем соціальної превенції $€$ насильство серед інтимних партнерів.

До групи підвищеного ризику щодо гендернозумовленого насильства відносяться, зокрема, жінки 3 наркозалежністю та жінки, які надають сексуальні послуги. Вони часто страждають від насильства, не завжди 
здатні його ідентифікувати і, як правило, не звертаються за допомогою до соціальних працівників, психологів, медиків, правоохоронних органів, щоб вирішити ситуацію, в якій проти них застосовується насильство. Їм важко відповідати своїй гендерній ролі через високий рівень стигматизації, низьку самооцінку, нав'язані суспільством стереотипи; тому часто така жінка вважає, що поруч з нею не може бути нікого іншого, окрім людини, від насильства якої вона страждає.

Крім домашнього фрізичного насильства існують також інші його види. Громада не завжди охоче сприймає тему насильства, оскільки у традиційних суспільствах може бути схильність до того, щоб сприймати насильство як звичайне явище. Відчувається також потреба у безпечному алгоритмі опитування жертв насильства. Наркозалежні жінки часто страждають від дискримінації, не мають доступу до соціальних послуг, не мають кола близьких для підтримки, не мають можливості звертатися до поліції, тому часто стають заручницями деструктивних відносин та жертвами різних видів насильства.

Метою статті $є$ аналіз функціональних складових та аналіз ефективності технології WINGS як комплексного системного інструменту профрілактики та короткотривалого втручання з метою зниження ризику насильства до жінок з наркозалежністю, серед них, також - жінок, які надають послуги сексуального характеру.

Виклад основного матеріалу. Технологія "WINGS" (Women Initiating New Goals of Safety) розроблена групою соціальної інтервенції Колумбійського університету (Нью-Йорк, США) [2]. Вона спирається на ідеї та концепцію теорії соціального навчання А. Бандури [4; 6] та ії̈ адаптацію у моделі профрілактики насильства серед інтимних партнерів, скринінгу, короткотривалої інтервенції та направлення на лікування (модель IPV SBIRT Intimal Partners Violence, Screening, Brief Intervention And Referral To Treatment) [7].

"WING" $€$ технологією короткотривалого втручання та призначена для ідентифікації різних типів гендернозумовленого насильства серед наркозалежних жінок, дозволяє їм розробляти стратегії планування безпеки, зміцнювати свою мережу соціальної підтримки, визначати та отримувати доступ до різних послуг з метою зменшення ризиків виникнення гендерно-зумовленого насильства, "WINGS" може бути впроваджена впродовж одного сеансу, а також інтегруватися з консультуванням та тестуванням на ВІЛ, вона також може бути використана разом із лікувальними інтервенціями щодо ВІЛ-інфекції [8].

Основною формою психосоціальної інтервенції за технологією "WINGS" виступає опитування та анкетування, які містять у собі також поради та запитання, які, зокрема, включають та орієнтують респондентку на створення власного плану поведінки у ситуаціях, що можуть привести до насильства стосовно неї. Ця технологія є клієнт-орієнтованою методикою, яка не дає оцінку дій клієнтки, але дозволяє їй самостійно визначити ступінь ризику ситуації, в якій вона може опинитися. Таким чином, окрім інфоормування, клієнтка за допомогою відкритих запитань спонукається до створення власного плану безпеки щодо своїх дій у ситуаціях загрози фізичного або сексуального насильства.

Групове заняття за методикою "WINGS" складається $з$ наступних основних елементів:

1. Підвищення обізнаності щодо різних типів насильства. Фасилітатор запитує учасників, що вони знають про різні типи насильства, використовуючи підказки, які допомагають учасникам ділитися своїми знаннями. Координатор підсумовує те, що сказали учасники, і додає інформацію про види насильства, зокрема, фрізичне та емоційне насильство;

2. Анкетування. Учасники заповнюють анкети про ризик насильства у своїх стосунках. Анкети заповнюються окремо, при цьому всі учасники перебувають в одній кімнаті. Учасники обговорюють деякі питання та їхні відповіді і мають змогу по черзі звернутися до фасилітатора з метою пояснення деяких питань, коли це необхідно;

3. Зворотній зв'язок (залучення мотивації для протидії насильству та конфліктних стосунків). Посередник надає загальні відгуки щодо ризиків для групи на основі анкет; Фасилітатор пропонує продовжити сесію та надає адреси додаткових послуг, якщо були виявлені ризики

4. Планування безпеки для зменшення ризику впливу насильства. Фасилітатор пояснює, що таке план безпеки, і пропонує створити план на окремих сесіях, якщо це необхідно, пропонує учаснику поділитися контактами проекту 3 друзями, які зазнають насильства. Фасилітатор обговорює з учасниками питання безпеки, задає питання та спонукає до дискусії про те, що робити, коли жінка опиняється в ситуації підвищеної загрози фізичного або сексуального насильства стосовно себе;

5. Закриття сесії. Фасилітатор пропонує послуги 3 протидії насильства для тих, хто визначив ризики, і разом із учасниками робить підсумки сесії, про що вони дізналися та якими можуть бути наступні кроки.

За необхідності може застосовуватися комп'ютеризована версія "WINGS", ефективність використання якої, за даними проведеного дослідження, не поступається традиційній [9].

Серед складових структурних елементів "WINGS" у традиційній та комп'ютерній версіях можна зазначити такі:

Підвищення психологічної обізнаності (психоедукація). У традиційному варіанті складається з надання ведучим відомостей про ризики насильства у інтимному партнерстві та ризик віктимізації жінок у цьому партнерстві. Серед цієї інформації наводяться статистичні дані про високий рівень насильства щодо наркозалежних жінок, пускові механізми насильства, у тому числі ті, що пов'язані з вживанням психоактивних речовин. У знайомстві з різними типами насильства використовується "Колесо Влади та Контролю".

Цей інструмент (див. рис. 1) дозволяє наглядно ознайомитися 3 вісьма типами прояву насильства в інтимному партнерстві, окрім безпосереднього фрізичного та сексуального насильства:

- використання залякування. Залякування поглядом, діями, жестами. Ламання речей. Псування власних речей жінки. Знущання над тваринами. Демонстрація зброї;

- використання емоційного насильства. Зневага. Змушення жінки відчувати себе знеціненою. Використання образливих прізвиськ. Навіювання та дії з метою викликати у жінки почуття, що вона є божевільною. Маніпулювання "доказами" цього. Приниження жінки. Викликання почуття провини, зокрема, щодо вживання наркотиків;

- використання ізолювання. Контроль над діями жінки, над тим, що вона дивиться, з ким розмовляє, що читає, куди йде. Обмеження у зовнішніх контактах. Виправдання цих дій власними ревнощами;

- мінімізація, заперечення та звинувачення. Зменшення значущості насильства, уникнення серйозної розмови на цю тему. Розмова про те, що насильства не було. Перекладання на жінку відповідальності за власну насильницьку поведінку. Звинувачення її в цьому, зокрема, через вживання наркотичних речовин;

- використання дітей. Викликання у жінки почуття провини щодо її дітей. Використання дітей для передавання повідомлень. Використання відвідування дітей 3 метою домагання. Загрози забрати дітей у жінки; 
- використання чоловічих привілеїв. Поводження 3 жінкою як з прислугою. Самостійне вирішення найважливіших питань. Авторитарна поведінка. Самостійне призначення чоловіком обов'язків для жінки;

- використання економічного насильства. Запобігання тому, щоб жінка отримала роботу чи залишилась працювати на робочому місці. Примушування до того, щоб жінка просила гроші, отримувала дозвіл на їх використання. Відбирання у неї грошей. Приховування інформації про сімейний прибуток та обмеження допуску до нього;

- використання примусу та загроз. Полягає в загрозі або здійсненні загрози зробити жінці боляче, загрозі ії̈ залишити, загрозі скоїти суїцид, загрозі поскар- житись на неї робітниками служби соціального забезпечення, примусі до здійснення злочину.

У комп'ютеризованому варіанті "WING" використовуються відеосвідчення від жінок щодо їх досвіду переживання різних видів насильства у інтимному партнерстві та його негативних наслідків, інтерактивна презентація загроз типів насильства з використанням "Колеса Влади та Контролю", візуальна презентація щодо пускових механізмів насильства серед інтимних партнерів, зокрема, до наркозалежних жінок.

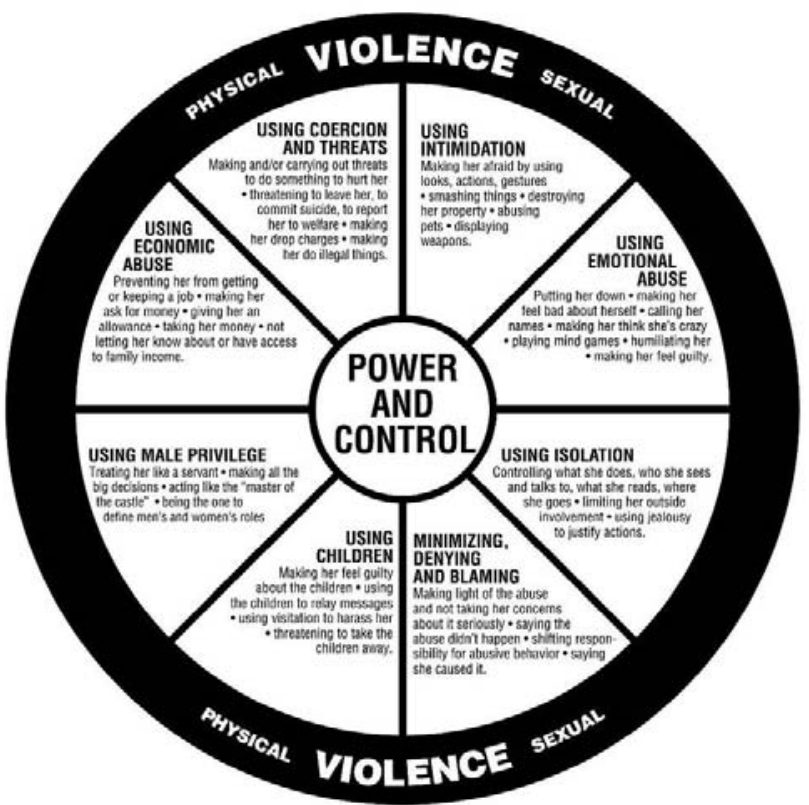

Рис. 1. Дулуське Колесо Влади та Контролю [10].

Підсилення мотивації щодо зміцнення безпеки у стосунках. Ведучий просить учасників ідентифікувати потенційний негативний вплив конфліктів та насильства серед інтимних партнерів на їх фрізичне та психічне здоров'я, їхнє благополуччя та благополуччя їхніх дітей. Після цього ведучий обговорює мотивацію учасників до зміцнення безпеки у стосунках.

У комп'ютеризованому варіанті "WING" учасники виокремлюють негативні ефекти конфліктів та насильства у інтимних стосунках на їх фрізичне та психічне здоров'я, їхнє благополуччя та благополуччя їхніх дітей з меню, яке випадає, та ідентифікують мотиваційні чинники щодо зміцнення безпеки у стосунках зі списку, який випадає.

Скриніне та оцінка ризику насильства у партнерських стосунках. Ведучий пропонує учасникам Переглянуту Шкалу Конфрліктної Тактики (Revised Conflict Tactics Scale - CTS2), що включає субшкали фрізичного, травматичного, вербального й сексуального насильства та Опитувальник Жорстокого Поводження 3 Жінкою (Psychological Malfunction Woman Inventory $\mathrm{PMWI})$, який оцінює ступінь ризику (високий, помірний або низький) психологічного насильства у їхніх інтимних стосунках. Після цього фасилітатор інформує учасників про те, який ризик насильства $є$ у їхніх стосунках з інтимними партнерами.

У комп'ютеризованому варіанті оцінка за цими методиками проводиться у формі аудіального самоінтерв'ювання (Audio Computer-Assisted Self-Interview ACASI). Після цього учасники отримують комп'ютеризований зворотний зв'язок щодо ступеня ризику (високого, помірного або низького) насильства у їхньому інтимному партнерстві.
Планування безпеки. Ведучий запитує учасників про те, як різні елементи планування безпеки можуть знизити ризик насильства серед інтимних партнерів у їхньому житті, використовуючи Перевірочний Список Планування Безпеки (Safety Planning Checklist), розроблений експертами Панелі національного консенсусу щодо насильства в інтимному партнерстві серед осіб, які вживають наркотичні речовини.

Комп'ютеризований варіант також пропонує роботу щодо планування безпеки за цією методикою.

збільшення соціальної підтримки. Ведучий пропонує учасникам визначити членів сім'ї, друзів, до яких вони можуть звернутися для підтримки, поради чи практичної допомоги щодо попередження або зниження ризику насильства у їхньому інтимному партнерстві, вирішення консрліктів у стосунках. Після цього пропонується визначити кроки, які вони будуть робити для зміцнення різних видів підтримки протягом наступного тижня.

У комп'ютеризованому варіанті учасникам пропонується розглянути інтерактивне "дерево" соціальної мережі підтримки, яке спонукає їх ідентифікувати до п'яти членів сімей та друзів, до яких вони можуть звернутися для підтримки, поради чи практичної допомоги щодо попередження або зниження ризику насильства у їхньому інтимному партнерстві та вирішення конфлліктів у стосунках. Після цього учасники спонукаються до визначення кроків, які вони будуть робити для зміцнення різних видів підтримки у найближчі дні.

Встановлення цілей щодо профілактики або зниження ризику насильства серед інтимних партнерів. Ведучий просить учасників визначити цілі 
щодо безпеки у особистих стосунках, які можуть містити такі варіанти:

1) залишитися разом, нічого не змінювати;

2) залишитися разом, зупинити насильство в інтимному партнерстві;

3) розлучитися з партнером та не підтримувати подальших контактів;

4) розлучитися з партнером, але бути в контакті та піклуватись про спільних дітей.

Після цього ведучий просить учасників визначити інші кроки, які вони можуть робити щодо встановлених цілей.

У комп'ютеризованому варіанті також пропонується визначення цілей. Серед можливих кроків учасник може ідентифрікувати такі, як пошук та знаходження іншого місця проживання, місця роботи, отримання консультативної підтримки та легальної допомоги, уникнення вживання алкоголю та інших наркотичних засобів.

Визначення потреб у допомозі соціальних служб ma іниих установ. Ведучий допомагає учасникам ідентифікувати та встановити пріоритети щодо сервісів, у яких вони мають потребу, і направити їх до відповідних служб. Після цього ведучий пропонує спланувати покроковий план дій на наступний тиждень щодо отримання послуг, надає друковану інформацію щодо послуг та роздруковує план безпеки для кожного учасника.

У комп'ютеризованому варіанті використовується програма, яка містить у собі ті ж самі елементи та можливість отриманням кожним учасником друкованої інформації та роздрукованого плану безпеки [9].

\section{Результати емпіричного дослідження}

Вибірку дослідження склали 20 жінок з наркозалежністю, які мають досвід скоєного проти них насильства. Окрім цього, з метою оцінювання якісної складової технології "WINGS" було проведене глибинне інтерв'ювання 2-х фахівців (психолога та соціального працівника) незалежної урядової організації з надання послуг ВІЛінфікованим, які мали досвід проведення інтервенції за методикою "WINGS". Іншим засобом оцінювання якісних характеристик цієї технології було проведення двох фокус-груп серед 12 учасниць, які отримали досвід проходження "WINGS у якості клієнток.

Інтервенція "WINGS" була проведена для двох груп осіб, які раніше не мали досвіду участі у сесіях "WINGS" - жінок, що живуть з наркозалежністю та жінок, які надають сексуальні послуги. Під час сесії клієнтки отримали опитувальник, який є одним із методичних інструментів сесії. За допомогою опитувальника було зібрано інформацію про цілі, які поставила перед собою учасниця і її потреби у спрямовуванні для отримання послуг. Ці дані були використані для порівняння з даними повторного опитування.

Повторне опитування учасниць інтервенції було проведено за допомогою анкети з відкритими та закритими запитаннями, щоб отримати від учасниць зворотній зв'язок про досвід участі у сесії "WINGS" та зміни у їхній поведінці після інтервенції, а також отримання інформації щодо того, чи вдалося їм виконати цілі та отримати послуги, які було визначено під час сесії. Анкетування клієнток було проведено через один календарний місяць за допомогою телефонного опитування. Такий спосіб було обрано через закритість цільової аудиторії та технічну складність повторно зібрати учасниць інтервенції. Респондентки відповіли на запитання про свій досвід участі у сесії "WINGS" та зміни своєї поведінки. Також, за допомогою ідентичного опитувальника, який був використаний під час участі в інтервенції, було проведено аналіз даних щодо того, чи виконали учасниці свої цілі та отримати послуги, які було визначено під час інтервенції.

Підбір респондентів здійснювався представниками неурядової організації (НУО), які контактують з предста- вниками вищезазначених груп. Соціальні працівники запрошували клієнтів організації або осіб, які не є клієнтами, але були запрошені опосередковано через знайомих клієнтів або соціальні мережі, взяти участь у дослідженні. Перед початком інтерв'ю проводився повторний усний скринінг опитуваних на відповідність критеріям включення в дослідження. Для створення безпечної та доброзичливої атмосфери спілкування зустрічі організовувались на базі НУО, клієнтами якої є респонденти.

Співробітники НУО були опитані безпосередньо на робочому місці. До участі у дослідженні були запрошені провайдери, що надають послуги жінкам з наркозалежністю та можуть детально описати існуючі послуги щодо зниження рівня насильства стосовно вищезазначених груп і надати інформацію щодо чинників усіх рівнів, які впливають на доступ до послуг протидії насильству, навести приклади успішних практик протидії насильства до жінок з наркозалежністю. Критеріями включення для учасниць інтервенції та фокус-груп був вік - не менше 18 років, досвід гендерно-зумовленого насильства стосовно себе, наркозалежність та можливість надати усну інформовану згоду. Критеріями виключення була нездатність надати інформовану згоду на участь у дослідженні. Перед проходженням опитування кожен потенційний учасник, який виявить зацікавленість до участі, проходитиме через процес надання письмової інфрормованої згоди взяти участь у дослідженні.

За результатами емпіричного дослідження були отримані наступні кількісні дані:

1) 20 з 20 учасниць інтервенції (100\%) створили свій власний план безпеки;

2) 12 з 20 жінок (60 \%) використали план безпеки за час проведення інтервенції;

3) 15 з 20 жінок (75 \%) змінили певні позиції у своїй мережі соціальної підтримки після участі у сесії "WINGS";

4) 1 з 20 учасниць (5 \%) отримувала послуги профрілактики гендерно-зумовленого насильства або насильства з боку статевого партнера до того, як прийняти участь у проекті "WINGS";

5) 19 з 20 жінок (95 \%) відзначили, що участь у сесії "WINGS" була для них корисною.

Провайдери послуг жінкам у ситуації насильства, називають свій досвід використання методології "WINGS" корисним та позитивним. Їм сподобалося, що інструмент "WINGS" орієнтований на потреби клієнтки, відповідає жінкам, якою є ситуація і ризик насильства наразі, і пропонує стратегії зменшення ризику насильства на основі переваг, очікувань та ресурсів. Фахівці вважають, що інструмент "WINGS" також відкриває можливості для їх організації отримувати більше ресурсів для протидії насильства та вирішення проблем їх пацієнтів, які пережили насильство. Клієнти знайшли корисну інформацію щодо різних типів насильства, виявили ризики у своїх відносинах. Разом із такими позитивними оцінками, фрасилітатори та учасники відзначили певні обмеження щодо використання "WINGS", зокрема, занадто довгу скринінгову форму, план безпеки, який застосовується лише для тих, хто стикається 3 насильством зараз та продовжує жити зі своїм партнером.

Окрім цього, було проведено дві фокус-групи, учасницями яких були жінки, що живуть із наркозалежністю (4 особи, які мали досвід участі в інтервенції "WINGS") та жінок, які надають сексуальні послуги (8 осіб, які не мали досвіду участі в інтервенції "WINGS") за спеціально розробленим для даного дослідження керівництвом для проведення такого інтерв'ю. Фокус групи були записані на цифровий аудіопристрій (диктофон) з можливістю дослівного транскрибування для подальшого тематичного аналізу.

Першу фокус-групу було проведено з чотирма клієнтками, з якими обговорювався їх досвід участі у сесії 
"WINGS". Всі учасниці завершили участь у сесії "WINGS" приблизно за два місяці до проведення фокусгрупи. Жодна з респонденток до участі в сесії "WINGS" не зверталась за допомогою у ситуації насильства.

Всі учасниці говорили про недоліки не стільки самої методології, як необхідності розробки подальших чітких стратегій допомоги жінкам, що постраждали від насилля. Дві з учасниць вбачають за потрібне залучити до адаптованої методики більше конкретних порад та технік. Серед недоліків подальшої роботи з жінками, що постраждали від насильства, учасниці назвали повільне та невчасне спрямовування за подальшою допомогою. Учасниці вважають, що необхідно ефективніше поширювати інформацію про сесії "WINGS" та допомогу в ситуації насильства. Дві з учасниць вважають, що потрібно мотивувати жінок, які отримали допомогу, більше розповідати про це своїм знайомим жінкам. Всі учасниці отримали корисну інфрормацію про вирішення конфрліктних ситуацій у стосунках та були поінформовані щодо ризиків таких конфрліктів. Загалом, учасниці позитивно оцінили методологію. Для розробки окремого плану безпеки для жінок, які надають сексуальні послуги, було зібрано інформацію, щодо використання успішних практик жінок, які надають сексуальні послуги, з якими було проведено фокус-групу, яка складалась з 8-ми учасниць.

За результатами проведення цієї фрокус-групи було виявлено, що п'ять з восьми респонденток $(63 \%)$ пережили фрізичне насильство за останній рік в результаті надання послуг сексуального характеру. При цьому семеро з восьми (88 \%) учасниць стикалися з фрізичним насильством під час всього періоду надання сексуальних послуг. Усі учасниці повідомили, що клієнти примушували їх до сексу, чи окремим практикам. Четверо 3 восьми респонденток (50 \%) відчували себе у безпеці зі своїм партнером протягом останнього року, двоє - не мали партнера, двоє - не відчували себе в безпеці. Шестеро 3 восьми респонденток $(78 \%)$ не відчували себе в безпеці через робітників поліції. Щодо використання презервативів, вісім з восьми учасниць (100\%) завжди домовлялися про використання презервативу 3 клієнтом. четверо із восьми учасниць (50 \%) непомітно для клієнта використовували презерватив у випадках, коли не вдавалося домовитися про його використання. У семеро із восьми респонденток (88 \%) була можливість зателефонувати за допомогою у ситуації насильства, проте, вони не мали контактів гарячої лінії, а номери довірених людей не були запрограмовані для швидкого набору на телесроні. Учасниці фрокус-групи підкреслювали, що в кожному конкретному випадку жінка, яка надає сексуальні послуги, має діяти, аналізуючи унікальну ситуацію, яка склалася, і саме від швидкості і якості такого аналізу залежить ії̈ життя і здоров'я. Одна 3 учасниць повідомляє, що для захисту їй був корисним курс самооборони. Двоє учасниць вважають небезпечним використання газового балончику. Троє з учасниць повідомили про використання контролю над кількістю вжитого алкоголю партнером як способу втечі у кризовій ситуації. Під час обговорення стандартного плану безпеки методології для жінок, що живуть 3 наркозалежністю, було виявлено, що жодна з учасниць не вважає, що ефрективно буде намагатися залишатися зверху під час сексу з партнером, щоб втекти, якщо потрібно. Жодна з учасниць не вважає, що ефективно буде сказати партнерові, що йдеш побачити члена сім'ї або подругу, у яких неприємності.

Всі учасниці погодились з твердженням, що ефективним $€$ чітко і спокійно пояснювати партнеру, що не бажаєш займатися сексом. Семеро із восьми учасниць вважає, що для зміцнення безпеки корисно буде всі важливі особисті речі та одяг тримати в одному місці, так щоб швидко піти і збагнути, як це зробити найлегше. Вісім із восьми учасниць вважає, що необхідно тримати відкладені гроші для критичних випадків або кредитну картку в сумочці, щоб взяти таксі або доїхати громадським транспортом до безпечного місця. Четверо із восьми учасниць вважають за необхідне написати повідомлення або зателефонувати людям із довірених контактів, щоб попросити притулку або зустрітися. Також жінки, які надають сексуальні послуги, повідомили, що вони були обізнані з базовими принципами захисту від зараження вірусом імунодефріциту людини та інфекцій, що передаються статевим шляхом. Щоб не завагітніти від партнера, всі респондентки назвали єдиний засіб - презерватив.

За результатами фрокус-груп, незважаючи на високу поширеність насильства, всі ці жінки повідомляли про обмеження щодо отримання послуг. Ці обмеження включали в себе відсутність допомоги у догляді за дітьми, відсутність притулків, які приймають наркозалежних жінок чи пропонують замісну підтримувальну терапію. Серед проблемних питань називалося безробіття, відсутність знань та навичок отримувати допомогу, розбудовувати соціальні взаємини. Фокус-групи виявили, що соціальна підтримка, допомога в отриманні замісної підтримувальної терапії, доступ до медичних послуг лікарів, толерантних до наркозалежних жінок, а також консультації соціального працівника, який проходив навчання щодо протидії гендерно-зумовленому насильству, допоможе підвищити безпеку та зменшити ризик конфрліктів та насильства, а також полегшить отримання інших необхідних послуг.

Враховуючи те, що досвід, яким поділились учасниці фокус-групи жінок, які надають сексуальні послуги, $є$ унікальним та суттєво відрізняється від досвіду інших жінок, було розроблено окремий план безпеки для них 3 урахуванням професійних особливостей клієнток. Також в план безпеки методології "WINGS", адаптований для жінок, які надають сексуальні послуги, було включено додаткові рекомендації для жінок, які надають сексуальні послуги та самостійно проводять перемовини $з$ клієнтом: рекомендовано використовувати розроблений короткий психологічний скринінг, що може виявити схильність до насильства при першій розмові з клієнтом, а також домовитись про конкретні практики, використовувати сучасні технічні можливості (Viber, Google Maps) та контакти зі знайомими для підвищення рівня безпеки та захисту життя.

Висновки. Технологія "WINGS" є однією із сучасних методик інформативно-інтервенційного комплексної дії, спрямованої на профілактику та протидію насильству щодо жінок з підвищеної групи ризику: наркозалежних жінок, та жінок, які надають сексуальні послуги. Дослідження показали достатньо високу ефективність як традиційного контактного, так і комп'ютеризованого варіанту використання цієї методики. Пілотний проект дослідження застосування технології "WINGS" в Україні показав результати, які дозволяють робити припущення щодо її достатньо ефективності. Разом із тим від допоміг виявити елементи, які потребують адаптації та удосконалення. Проведені фокус-групи виявили якісні елементи ефрективності, зокрема, у плануванні безпеки та профрілактики насильства серед інтимних партнерів. Окрім цього, можна судити про нагальну потребу у проведенні емпіричного дослідження щодо адаптації та ефективності технології "WINGS" на більш численній, репрезентативній виборці.

Автори висловлюють подяку Eurasian Key Populations Health Network (EKHN) за надання технічної підтримки та ГО "Клуб "Еней" за надання технічної бази для проведення дослідження.

Список використаних джерел

1. Скорбатюк А. Реабілітаційні моделі надання послуг в Німеччині / А.Скорбатюк // Вісник Київського національного університету імені Тараса Шевченка. Соціальна робота. - 2017. - 2(2). - С. 45-48. 
2. Social Intervention Group (SIG), COLUMBIA UNIVERSITY IN THE CITY OF NEW YORK, evidence-based tool entitled WINGS (Women Initiating New Goals of Safety). - Режим доступу: http://projectwings.org/

3. Тохтамиш О.М. Стратегія фокусування на вирішенні в консультативній соціальній роботі / О.М. Тохтамиш // Вісник Київського національного університету імені Тараса Шевченка. Соціальна робота. - 2017. - 2(2). - С. 19-25.

4. Максимова Н. Типологія сімей, які потребують соціально-психологічної допомоги / Н.Максимова // Вісник Київського національного університету імені Тараса Шевченка. Соціальна робота. - 2017. - 1(1). - С. 45-50.

5. Bandura A (1992) A social cognitive approach to the exercise of control of AIDS infection. In DiClemente, RJ (ed) Adolescents and AIDS: A Generation in Jeopardy. Newbury Park, CA: Sage, 89-116.

6. Bandura A (1994) Social cognitive theory and exercise of control over HIV infection. In: DiClemente RJ, Peterson JL (eds.) Preventing AIDS: Theories and Methods of Behavioral Interventions. New York: Plenum Press. 25-29.

7. Eckhardt Cl, Murphy CM, Whitaker DJ, Sprunger J, Dykstra R (2013) The effectiveness of intervention programs for perpetrators and victims of intimate partner violence. Partner Abuse 4: 196-231.

8. Gilbert L., Goddard-Eckrich D., Hunt T., Ma X., Chang M., Rowe J., McCrimmon T., Johnson K., Goodwin Sh., Almonte M., Shaw S. A., (2016). Efficacy of a Computerized Intervention on HIV and Intimate Partner Violence Among Substance-Using Women in Community Corrections: A Randomized Controlled Trial. American Journal of Public Health, 106, 7, 1278-86. doi: 10.2105/AJPH.2016.303119.

9. Gilbert L., Shaw S. A., Goddard-Eckrich D., Chang M., Rowe J., McCrimmon T., Almonte M., Goodwin Sh., Epperson M. (2015). Project WINGS (Women Initiating New Goals of Safety): A randomised controlled trial of a screening, brief intervention and referral to treatment (SBIRT) service to identify and address intimate partner violence victimisation among substance-using women receiving community supervision. Criminal Behaviour and Mental Health, 10;25(4):314-29. doi: 10.1002/cbm.1979.

10. Domestic abuse intervention programs. - Режим доступу: https://www.theduluthmodel.org/

Referenses

1. Skorbatiuk A. (2017). Reabilitatsiini modeli nadannia posluh v Nimechchyni. Visnyk Kyivskogo natsionalnogo universytetu imeni Tarasa Shevchenka. Socialna robota, 2(2), 45-48

O. Tokhtamysh, Ph.D. in Psychology, docent

Taras Shevchenko National University of Kyiv, Kyiv, Ukraine

ORCID iD 0000-0002-3850-535X

V. Parkhomenko, M.A. in Psychology

NGO "Club Eney", Kyiv, Ukraine

ORCID iD 0000-0003-4400-7397

A. Sarnatska, Chief Researcher,

NGO "Club Eney", Kyiv, Ukraine

ORCID iD 0000-0002-5253-291X
2. Social Intervention Group (SIG), COLUMBIA UNIVERSITY IN THE CITY OF NEW YORK, evidence-based tool entitled WINGS (Women Initiating New Goals of Safety); http://projectwings.org/

3. Tokhtamysh, O.M. (2017). Strategiya fokusuvannya na vyrishenni v konsultatyvnii socialnii roboti. Visnyk Kyivskogo natsionalnogo universytetu imeni Tarasa Shevchenka. Socialna robota, 2(2), 19-25.

4. Maksymova N. (2017). Typolohiia simei, yaki potrebuiut sotsialnopsykholohichnoi dopomohy. допомоги Visnyk Kyivskogo natsionalnogo universytetu imeni Tarasa Shevchenka. Socialna robota, 1(1), 45-50.

5. Bandura A (1992) A social cognitive approach to the exercise of control of AIDS infection. In DiClemente, RJ (ed) Adolescents and AIDS: A Generation in Jeopardy. Newbury Park, CA: Sage, 89-116.

6. Bandura A (1994) Social cognitive theory and exercise of control over HIV infection. In: DiClemente RJ, Peterson JL (eds.) Preventing AIDS: Theories and Methods of Behavioral Interventions. New York: Plenum Press. 25-29.

7. Eckhardt Cl, Murphy CM, Whitaker DJ, Sprunger J, Dykstra R (2013) The effectiveness of intervention programs for perpetrators and victims of intimate partner violence. Partner Abuse 4: 196-231.

8. Gilbert L., Goddard-Eckrich D., Hunt T., Ma X., Chang M., Rowe J., McCrimmon T., Johnson K., Goodwin Sh., Almonte M., Shaw S. A., (2016). Efficacy of a Computerized Intervention on HIV and Intimate Partner Violence Among Substance-Using Women in Community Corrections: A Randomized Controlled Trial. American Journal of Public Health, 106, 7, 1278-86. doi: 10.2105/AJPH.2016.303119.

9. Gilbert L., Shaw S. A., Goddard-Eckrich D., Chang M., Rowe J., McCrimmon T., Almonte M., Goodwin Sh., Epperson M. (2015). Project WINGS (Women Initiating New Goals of Safety): A randomised controlled trial of a screening, brief intervention and referral to treatment (SBIRT) service to identify and address intimate partner violence victimisation among substance-using women receiving community supervision. Criminal Behaviour and Mental Health, 10;25(4):314-29. doi: 10.1002/cbm.1979.

10. Domestic abuse intervention programs. https://www.theduluthmodel.org/

$$
\text { Надійшла до редколегії 01.11.18 }
$$

Рецензовано 12.11.18

\section{"WINGS" TECHNOLOGY AS A MEANS OF COUNTERACTION TO VIOLENCE AGAINST WOMEN FROM A HIGH RISK GROUP}

This topic is actual in the context of high levels of violence against drug addicted women and women in sex industry and insufficient opportunity for them to apply for relevant social services in Ukraine.

The article considers the functional components of the complex preventive and rehabilitation technology "Women Initiating New Goals of Safety", developed by a group social intervention of the Columbia University (USA) in order to reduce the risk of violence against women with drug dependence. This technology was adapted and applied for a pilot project to verify its effectiveness in Ukraine.

The sample of the study consisted of 20 women with drug addiction who have experience of violence against them. In addition, in order to assess the qualitative component of the WINGS technology, an in-depth interview was conducted by 2 experts (psychologist and social worker) of an independent governmental organization to provide services to HIV-infected people, who had the experience of conducting an intervention using the method "WINGS". Another tool for evaluating the qualitative characteristics of this technology was the sessions of two focus groups of 12 participants who had the experience of passing WINGS as clients. A separate plan for security was developed for women who works in sex industry, taking into account, that the experience shared by participants in the focus groups of them is unique and significantly different from the experience of other women. Conducted focus groups found elements of quality performance, especially in the security planning and prevention of violence among intimate partners.

Providers, who give services to the situation of violence, appreciate their experience of using the WINGS methodology as useful and positive.

Pilot studies of using the "WINGS" technology in Ukraine showed results, that allow us to make the previous assumptions about its significant efficiency. At the same time, it helped identify the elements that need to be adapted and refined.

Keywords: prevention of violence, women with drug addiction, short-term intervention, gender-based violence, social service.

А. Тохтамыш, канд. психол. наук, доц.

Киевский национальный университет имени Тараса Шевченко, Киев, Украина

ORCID iD 0000-0002-3850-535X

В. Пархоменко, магистр

ОО клуб "Еней", Киев, Украина

ORCID ID 0000-0003-4400-7397

А. Сарнацкая, головный специалист

ОО Клуб "Еней", Киев, Украина

ORCID ID 0000-0002-5253-291X

\section{TЕХНОЛОГИЯ "WINGS" КАК СРЕДСТВО ПРОТИВОДЕЙСТВИЯ НАСИЛИЮ ПО ОТНОШЕНИЮ К ЖЕНЩИНАМ ИЗ ГРУППЫ ПОВЫШЕННОГО РИСКА}

Рассматриваются функциональные составляющие комплексной профилактической и реабилитационной технологии "WINGS" (Women Initiating New Goals of Safety), разработанной группой социальной интервенции Колумбийского университета (США), с иелью снижения рисков насилия по отношению к женщинам с наркозависимостью и женщинам, которые предоставляют сексуальные услуги. Анализируются результаты эмпирические исследования ее эффективности в ее использовании в качестве пилотного проекта в Украине. Предлагаются рекомендации и возможности ее усовершенствования с полученных результатов.

Ключевые слова: профилактика насилия, женщины с наркозависимостью, кратковременное вмешательство, гендернообусловленное насилие, социальное сопровождение. 